\title{
Level of Albuminuria and Risk of Stroke: Systematic Review and Meta-Analysis
}

\author{
Meng Lee ${ }^{a, b, d}$ Jeffrey L. Saver ${ }^{a}$ Kuo-Hsuan Chang ${ }^{c, d}$ Bruce Ovbiagele ${ }^{a}$ \\ aStroke Center and Department of Neurology, University of California, Los Angeles, Calif., USA; ${ }^{b}$ Department of \\ Neurology, Chang Gung Memorial Hospital at Chiayi, 'Department of Neurology, Chang Gung Memorial Hospital \\ at Linkou, and ${ }^{d}$ Chang Gung University College of Medicine, Chang Gung, Taiwan, ROC
}

\section{Key Words}

Albuminuria $\cdot$ Dose-response $\cdot$ Macroalbuminuria $\cdot$

Meta-analysis $\cdot$ Microalbuminuria $\cdot$ Proteinuria $\cdot$ Stroke $\cdot$

Systematic review $\cdot$ Urinary albumin excretion

\begin{abstract}
Background: Gross albuminuria is associated with increased stroke risk, but it is unclear whether stroke incidence varies by level of albuminuria. We meta-analyzed prospective cohort studies to investigate the impact of various albuminuria levels and continuous urinary albumin excretion (UAE) change on stroke risk. Methods: Systematic search for studies reporting quantitative estimates of the multivariate-adjusted relative risk (RR) and $95 \% \mathrm{Cl}$ for stroke risk associated with microalbuminuria (UAE $30-300 \mathrm{mg} /$ day or nearest equivalent interval) and macroalbuminuria (UAE $>300 \mathrm{mg} /$ day) and studies that analyzed the relation of stroke with UAE continuously. Estimates were combined using a random-effect model. Results: We identified seven studies comprising 46,638 participants with 1,479 stroke events. Incident stroke risk was greater for macroalbuminuria (RR 2.65, $95 \% \mathrm{Cl} 2.25-3.14$ ) than microalbuminuria (RR $1.58,95 \% \mathrm{Cl}$ 1.39-1.80), a difference that was significant ( $p$ for heterogeneity $\left.<0.001, I^{2}=96 \%\right)$. In addition, risk of stroke increased
\end{abstract}

proportionally with rising UAE ( $p<0.001)$, even for UAE within normal range (beginning from levels as low as $2-4 \mathrm{mg} / \mathrm{g}$ ). Conclusions: Higher albuminuria level confers greater stroke risk. These findings provide additional weight to evidence that albuminuria is strongly linked to stroke risk, and suggest that persons with elevated UAE levels may especially benefit from more intensive vascular risk reduction.

Copyright $\odot 2010$ S. Karger AG, Basel

\section{Introduction}

Presence of overt proteinuria has been independently linked to greater stroke risk [1]. Furthermore, emerging data suggest that microalbuminuria may boost stroke risk [2], but the full extent of the relationship between urinary albumin excretion (UAE) and stroke has not been established. Specifically, it is not clear whether there is a greater risk of stroke with progressively higher levels of albuminuria. In this study, we utilized a systematic review and meta-analysis to assess: (1) the impact of various levels of albuminuria and macroalbuminuria on incident stroke risk, and (2) the influence of continuous change in level of UAE on risk of stroke.

\section{KARGER}

๑) 2010 S. Karger AG, Basel

Fax +41613061234 E-Mail karger@karger.ch www.karger.com www.karger.com/ced
Bruce Ovbiagele, MD, MS

UCLA Stroke Center

710 Westwood Plaza, University of California

Los Angeles, CA 90095 (USA)

Tel. +1 310794 6379, Fax +1 310267 2063,E-Mail Ovibes@ mednet.ucla.edu 
Fig. 1. Study selection flow.

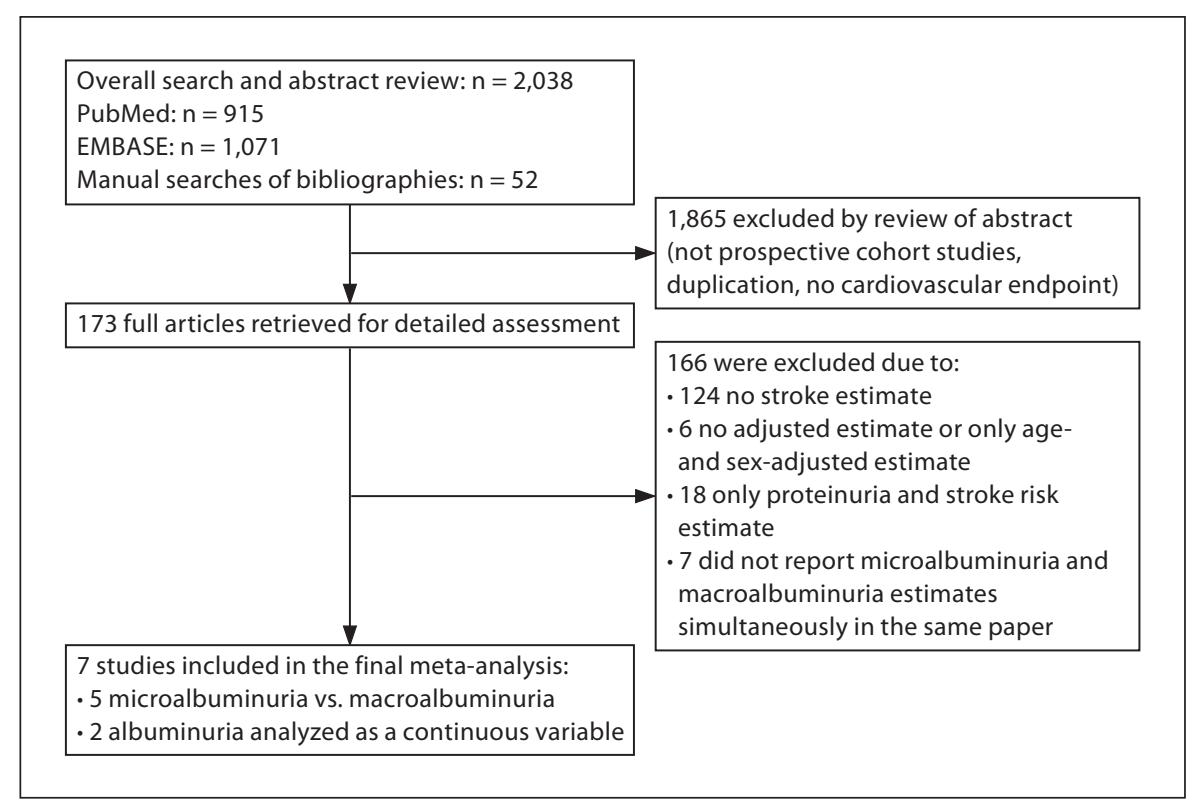

\section{Methods}

The search strategy was conducted according to the recommendations of the Meta-analysis of Observational Studies in Epidemiology [3]. We performed a systematic search of Pubmed (1966 to October 2009) and Embase (1947 to October 2009) using the following search strategy: 'proteinuria' or 'albuminuria' or 'microalbuminuria' or 'macroalbuminuria' or 'normoalbuminuria' or 'low grade albuminuria' crossed with 'stroke' or 'cerebrovascular disease' or 'cerebral ischemia' or 'brain ischemia' or 'intracranial hemorrhage'. Additionally, we identified potentially relevant studies using a manual search of references from all eligible studies and review articles. Studies were selected if they met the following entry criteria: (1) prospective cohort design; (2) reported quantitative estimates of multivariate-adjusted relative risk (RR) and 95\% CI for stroke risk associated with microalbuminuria and macroalbuminuria, separately, or provided relationship of stroke risk and albuminuria by analyzing albuminuria as continuous variables, and (3) follow-up duration was at least one year. Studies were excluded if (1) they were of cross-sectional, case-control, or retrospective cohort design; (2) a majority of the participants had chronic kidney disease, and (3) only reported unadjusted or age- and sex-adjusted RR.

Data analysis used multivariate-adjusted outcome data (expressed as RR and 95\% CI). We converted these values by using their natural logarithms, and standard errors were calculated from these logarithmic numbers and their corresponding 95\% CI. The inverse variance approach was used to combine log RR and standard errors and data pooled across trials using the random-effects model [using Cochrane Collaboration's Review Manager Software Package (RevMan 5)]. All reported p values were two-sided with significance $<0.05$. Heterogeneity was assessed by $\mathrm{p}$ value of $\chi^{2}$ statistics and $\mathrm{I}^{2}$. A funnel plot was conducted to evaluate potential systematic bias in studies, including publication bias.

Albuminuria Level and Stroke Risk

\section{Results}

Our final analysis (fig. 1) included five studies that compared stroke risk among subjects with baseline normoalbuminuria (UAE $<30 \mathrm{mg}$ /day or nearest equivalent interval), microalbuminuria (UAE 30-300 mg/day or nearest equivalent interval), and macroalbuminuria (UAE >300 mg/day) [4-8], generating six independent adjusted stroke risk estimates. Only two studies analyzed albuminuria level versus stroke risk as a continuous variable $[9,10]$. There were 46,638 participants with 1,479 stroke events included in the meta-analysis. Study characteristics can be found in table 1 .

Stroke risk was greater for macroalbuminuria (RR $2.65,95 \%$ CI 2.25-3.14) than microalbuminuria (RR 1.58, 95\% CI 1.39-1.80) and the test for difference between these two groups by level of albuminuria was highly significant ( $p$ for heterogeneity $<0.001, I^{2}=96 \%$; fig. $2 a$ ). When albuminuria levels were analyzed as a continuous variable, risk of stroke increased proportionally with rising albuminuria even starting within the normal range of albuminuria from levels as low as about $2-4 \mathrm{mg} / \mathrm{g}$ (fig. 2b). There was no major asymmetric appearance on the funnel plot (fig. 3). 
Table 1. Study characteristics

\begin{tabular}{|c|c|c|c|c|c|c|c|c|}
\hline Study & $\begin{array}{l}\text { Study design } \\
\text { and population }\end{array}$ & Country & $\mathrm{n} / \mathrm{N}$ & $\begin{array}{l}\text { Age mean } \pm S D \\
\text { years }\end{array}$ & $\begin{array}{l}\text { Follow-up } \\
\text { years }\end{array}$ & End point & $\begin{array}{l}\text { Definition of } \\
\text { albuminuria }\end{array}$ & $\begin{array}{l}\text { Adjusted variables (number } \\
\text { of adjusted variables) }\end{array}$ \\
\hline $\begin{array}{l}\text { Miettinen } \\
\text { 1996a [4] }\end{array}$ & $\begin{array}{l}\text { Non-diabetic } \\
\text { cohort, stroke } \\
\text { history at entry } \\
\text { was } 1 \%\end{array}$ & Finland & $30 / 1,375$ & $58 \pm 0.2$ & 7 & All stroke & $\begin{array}{l}\text { Microalbuminuria: } \\
\text { 150-300 mg/l } \\
\text { Macroalbuminuria: } \\
>300 \mathrm{mg} / \mathrm{l}\end{array}$ & $\begin{array}{l}\text { Age, sex, smoking, } \\
\text { hypertension, total } \\
\text { cholesterol, HDL } \\
\text { cholesterol, TG, area, } \\
\text { history of stroke (9) }\end{array}$ \\
\hline $\begin{array}{l}\text { Miettinen } \\
\text { 1996b [4] }\end{array}$ & $\begin{array}{l}\text { Type } 2 \text { diabetic } \\
\text { cohort, stroke } \\
\text { history at entry } \\
\text { was } 6 \%\end{array}$ & Finland & $125 / 1,056$ & $58 \pm 0.2$ & 7 & All stroke & $\begin{array}{l}\text { Microalbuminuria: } \\
\text { 150-300 mg/l } \\
\text { Macroalbuminuria: } \\
>300 \mathrm{mg} / \mathrm{l}\end{array}$ & $\begin{array}{l}\text { Age, sex, smoking, } \\
\text { hypertension, total } \\
\text { cholesterol, HDL } \\
\text { cholesterol, TG, area, } \\
\text { history of stroke (9) }\end{array}$ \\
\hline $\begin{array}{l}\text { Valmadrid } \\
2000[5]\end{array}$ & $\begin{array}{l}\text { Population-based } \\
\text { older-onset } \\
\text { diabetic cohort }\end{array}$ & USA & $85 / 840$ & $67 \pm 11$ & 12 & Fatal stroke & $\begin{array}{l}\text { Microalbuminuria: } \\
\text { 30-299 mg/l } \\
\text { Macroalbuminuria: } \\
\geq 300 \mathrm{mg} / \mathrm{l}\end{array}$ & $\begin{array}{l}\text { Age, sex, glycemic control, } \\
\text { insulin use, alcohol intake, } \\
\text { physical activity, history of } \\
\text { CVD, intake of anti- } \\
\text { hypertensive agents, } \\
\text { presence and severity of } \\
\text { diabetic retinopathy (10) }\end{array}$ \\
\hline $\begin{array}{l}\text { Yang } \\
2008[6]\end{array}$ & $\begin{array}{l}\text { Type } 2 \text { diabetic } \\
\text { clinic-based } \\
\text { cohort, no stroke } \\
\text { history at entry }\end{array}$ & China & $287 / 6,445$ & 57 (IQR 46-67) & 5.4 & $\begin{array}{l}\text { Ischemic } \\
\text { stroke }\end{array}$ & $\begin{array}{l}\text { Microalbuminuria: } \\
2.5-25 \mathrm{mg} / \mathrm{mmol} \text { in } \\
\text { men and } 3.5-25 \mathrm{mg} / \\
\text { mmol in women } \\
\text { Macroalbuminuria: } \\
\geq 25 \mathrm{mg} / \mathrm{mmol}\end{array}$ & $\begin{array}{l}\text { Age, sex, smoking status } \\
\text { (current and former), } \\
\text { hypertension, duration of } \\
\text { DM, HDL cholesterol, BMI, } \\
\text { eGFR, use of drugs at } \\
\text { baseline (lipid-lowering } \\
\text { drugs, oral anti-diabetic } \\
\text { drugs, and insulin) (11) }\end{array}$ \\
\hline $\begin{array}{l}\text { Yuyun } \\
2004[7]\end{array}$ & $\begin{array}{l}\text { Population-based } \\
\text { cohort, no stroke } \\
\text { history at entry }\end{array}$ & UK & $246 / 23,630$ & $58 \pm 9$ & 7.2 & All stroke & $\begin{array}{l}\text { Microalbuminuria: } \\
2.5-25 \mathrm{mg} / \mathrm{mmol} \\
\text { Macroalbuminuria: } \\
\geq 25 \mathrm{mg} / \mathrm{mmol}\end{array}$ & $\begin{array}{l}\text { Age, sex, smoking, systolic } \\
\text { BP, DM, total cholesterol, } \\
\text { BMI, physical activity, } \\
\text { family history of stroke, } \\
\text { baseline CHD, hypertension } \\
\text { treatment (11) }\end{array}$ \\
\hline $\begin{array}{l}\text { Zhang } \\
2008[8]\end{array}$ & $\begin{array}{l}\text { Population-based } \\
\text { cohort, stroke } \\
\text { history at entry } \\
\text { was } 1 \%\end{array}$ & $\begin{array}{l}\text { USA } \\
\text { (American } \\
\text { Indians) }\end{array}$ & $306 / 4,549$ & $57 \pm 9$ & 13.4 & All stroke & $\begin{array}{l}\text { Microalbuminuria: } \\
\text { 30-299 mg/g } \\
\text { Macroalbuminuria: } \\
\geq 300 \mathrm{mg} / \mathrm{g}\end{array}$ & $\begin{array}{l}\text { Age, sex, smoking, systolic } \\
\text { and diastolic BP, fasting } \\
\text { glucose, LDL and HDL } \\
\text { cholesterol, triglycerides, } \\
\text { BMI, waist circumference, } \\
\text { physical activity, alcohol } \\
\text { use (13) }\end{array}$ \\
\hline $\begin{array}{l}\text { Kistorp } \\
2005[9]\end{array}$ & $\begin{array}{l}\text { Population-based } \\
\text { cohort without } \\
\text { CVD history at } \\
\text { entry }\end{array}$ & Denmark & $21 / 537$ & $68 \pm 11$ & 5 & $\begin{array}{l}\text { Ischemic } \\
\text { stroke }\end{array}$ & $\begin{array}{l}\text { Lower limit of } \\
\text { albuminuria start } \\
\text { from } 1 \mathrm{mg} / \mathrm{l} \text {, } \\
\text { analyzed as per SD } \\
\text { increased }\end{array}$ & $\begin{array}{l}\text { Age, sex, current smoking, } \\
\text { hypertension, DM, total } \\
\text { cholesterol, AF, LVEF } \\
<50 \% \text {, LVH, serum } \\
\text { creatinine }(10)\end{array}$ \\
\hline $\begin{array}{l}\text { Wachtell } \\
2003[10]\end{array}$ & $\begin{array}{l}\text { HTN cohort } \\
\text { from a clinical } \\
\text { trial }\end{array}$ & $\begin{array}{l}\text { Interna- } \\
\text { tional }\end{array}$ & $379 / 8,206$ & $66 \pm 7$ & 4.8 & All stroke & $\begin{array}{l}\text { Lower limit of } \\
\text { albuminuria start } \\
\text { from } 0.25 \mathrm{mg} / \mathrm{mmol} \text {, } \\
\text { analyzed as every } \\
10 \text {-fold increase in } \\
\text { UACR }\end{array}$ & $\begin{array}{l}\text { Age, sex, smoking, left } \\
\text { ventricular mass by ECG, } \\
\text { serum creatinine level, race, } \\
\text { study treatment } \\
\text { allocation ( } 7 \text { ) }\end{array}$ \\
\hline
\end{tabular}

$\mathrm{AF}=$ Atrial fibrillation; $\mathrm{BP}=$ blood pressure $\mathrm{CHD}=$ coronary heart disease; $\mathrm{CVD}=$ cardiovascular disease; $\mathrm{DM}=$ diabetes mellitus; $\mathrm{ECG}=$ electrocardiography; $\mathrm{HF}=$ heart failure; $\mathrm{LVEF}=$ left ventricular ejection fraction; $\mathrm{LVH}=$ left ventricular hypertrophy; $\mathrm{MI}=$ myocardial infarct; $\mathrm{N}=$ number of participants; $\mathrm{n}=$ number of strokes; UACR = urine albumin creatinine ratio. 


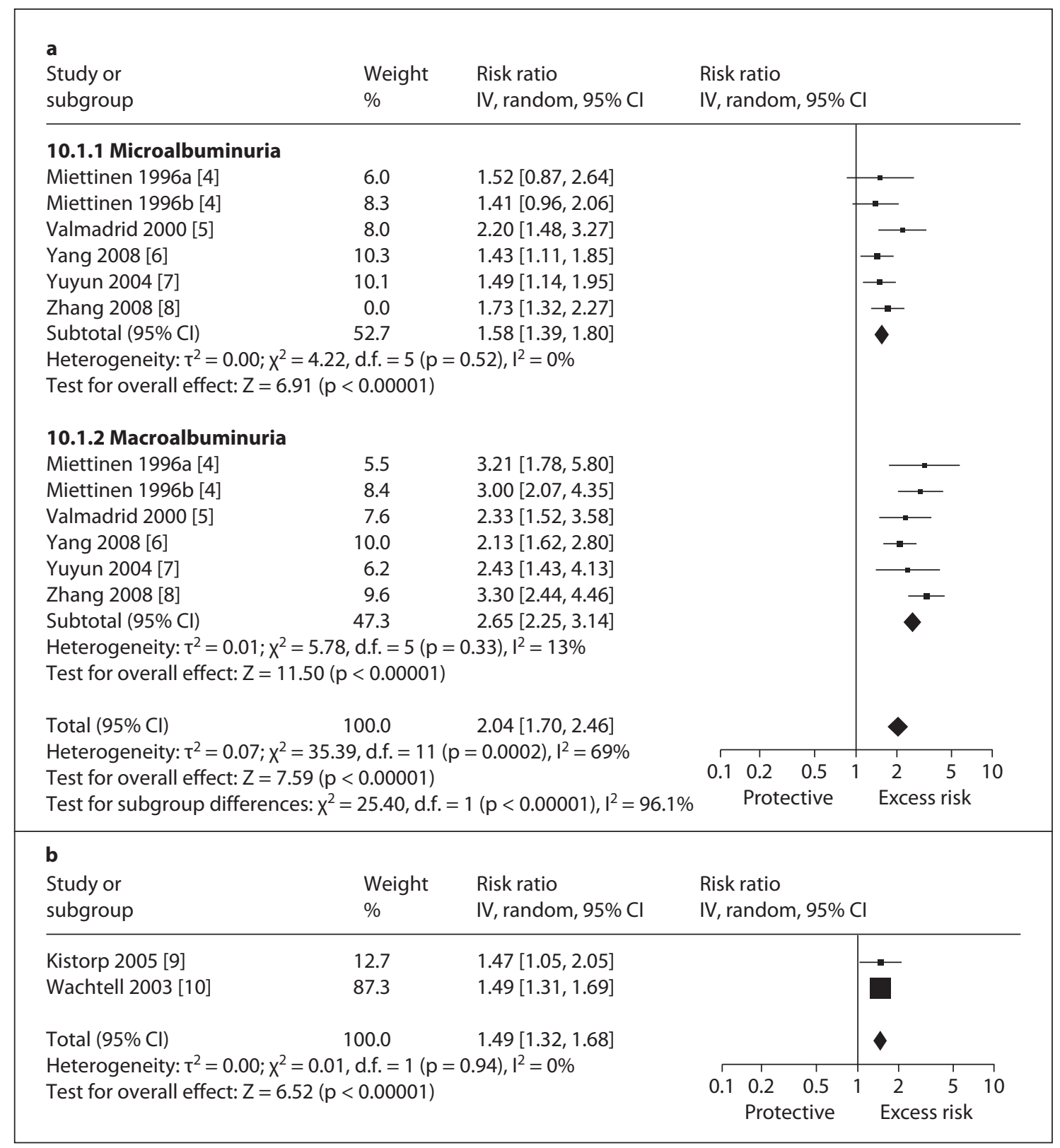

Fig. 2. Impact of albuminuria level on stroke risk. a Macroalbuminuria and microalbuminuria. b Albuminuria analyzed as a continuous variable (starting from normal albuminuria range).

\section{Discussion}

We found a significant and strong independent doseresponse relationship between albuminuria and incident stroke. Whether examined as two differing levels of albuminuria or continuously, greater degree of baseline albuminuria was linked to higher stroke risk. Our results are strengthened by several factors. Microalbuminuria and macroalbuminuria were reported separately in each study, and so we had the same reference (normoalbuminuria) across studies for comparison. Also, the inclusion of only prospective data lessened effects of selection and recall bias. Finally, the relatively large number of subjects enhances generalizability and incorporation of only multivariate-adjusted RR reduced influence of known confounders. 


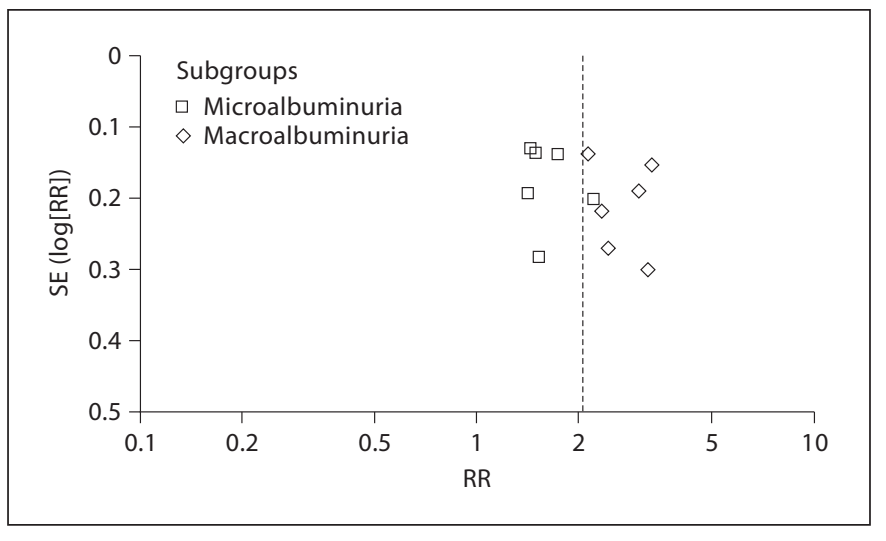

Fig. 3. Funnel plot evaluating potential systematic bias in studies included in the meta-analysis.

Interestingly, the studies in this review met several of the Hill criteria [11] for causation. First, an appropriate temporal relationship: albuminuria preceded stroke in all studies. Second, the findings were consistent with a doseresponse relationship, with stronger associations for macroalbuminuria relative to microalbuminuria and a positive relationship in continuous analysis. Third, there was consistency across all studies (fig. 2). Fourth, biological plausibility also existed, since albuminuria is commonly found among patients with diabetes who have symptomatic large vessel atherosclerosis (41\%), and this appears to be a strong independent predictor of future death from vascular causes $[12,13]$. Still, observational studies cannot prove causality and mechanistically it is unclear how albuminuria would directly cause stroke. It is more likely that both albuminuria and stroke closely share similar underlying pathophysiologic processes (e.g. generalized endothelial dysfunction) $[14,15]$, and albuminuria can serve as useful risk marker for future stroke risk, especially since obtaining urine samples is relatively cheap and simple. Persons with higher levels of albuminuria may be candidates for more intensive global vascular risk reduction, particularly using agents like statins and modulators of the renin angiotensin system, which have been shown to reduce albuminuria and prevent vascular events [14].

There are some limitations to our study. First, the statistical methods of population studies founded in probability theory may not necessarily reflect the unique causal pattern in a given patient. Second, since this was a study-level meta-analysis (not an individual-level metaanalysis), we were unable to apply a uniform adjustment for confounding variables to all studies. As such, our summary result could be an overestimation of the true magnitude of the link between albuminuria and stroke. However, the number of variables adjusted in the included studies ranged from 5 to 11 and comprised several factors such as hypertension [16], diabetes [17], and left ventricular dysfunction [18], which are well known to be associated with both stroke and albuminuria level, so we believe that any potential summary result overestimation by our study is likely modest. Third, although we found no major asymmetric appearance on the funnel plot, it is conceivable that a publication bias may exist such that only studies showing a relation between urine albumin levels and stroke risk have been published. Fourth, two studies which analyzed albuminuria as a continuous variable used different units of UAE increment, thus making a precise quantification of the overall magnitude of impact difficult. However, qualitatively the association was positive, and in both studies the stroke risk rose proportionally with rising UAE from very low levels within the normal range of albuminuria. Together with results from the microalbuminuria versus macroalbuminuria analysis, we believe that the evidence points in the direction of a dose-response relationship between baseline albuminuria and stroke risk.

\section{Acknowledgements}

Meng Lee (CMRPG 660311, Taiwan), Jeffrey L Saver (NIH SPOTRIAS), Bruce Ovbiagele (UCLA-RCMAR under NIH/NIA Grant P30-AG021684). We thank Yueh Lee, MSc for assistance with the article search.

References , Allagher M, Jardine M, Anderson Chalmers J, Craig JC, Huxley R: Proteinuria and stroke: a meta-analysis of cohort studies. Am J Kidney Dis 2009;53:417-425.

2 Ovbiagele B: Microalbuminuria: risk factor and potential therapeutic target for stroke? J Neurol Sci 2008;271:21-28.

3 Stroup DF, Berlin JA, Morton SC, Olkin I, Williamson GD, Rennie D, Moher D, Becker BJ, Sipe TA, Thacker SB: Meta-analysis of observational studies in epidemiology: a proposal for reporting. Meta-analysis of observational studies in epidemiology (moose) group. JAMA 2000;283:2008-2012.

4 Miettinen H, Haffner SM, Lehto S, Ronnemaa T, Pyorala K, Laakso M: Proteinuria predicts stroke and other atherosclerotic vascular disease events in nondiabetic and non-insulin-dependent diabetic subjects. Stroke 1996; 27:2033-2039. 
5 Valmadrid CT, Klein R, Moss SE, Klein BE: The risk of cardiovascular disease mortality associated with microalbuminuria and gross proteinuria in persons with older-onset diabetes mellitus. Arch Intern Med 2000;160: 1093-1100.

-6 Yang X, Ko GT, So WY, Ma RC, Kong AP, Lam CW, Ho CS, Chow CC, Tong PC, Chan JC: Additive interaction of hyperglycemia and albuminuria on risk of ischemic stroke in type 2 diabetes: Hong Kong diabetes registry. Diabetes Care 2008;31:2294-2300.

-7 Yuyun MF, Khaw KT, Luben R, Welch A, Bingham S, Day NE, Wareham NJ: Microalbuminuria and stroke in a British population: the European prospective investigation into cancer in Norfolk (EPIC-Norfolk) population study. J Intern Med 2004;255:247256.

$\checkmark 8$ Zhang Y, Galloway JM, Welty TK, Wiebers DO, Whisnant JP, Devereux RB, Kizer JR, Howard BV, Cowan LD, Yeh J, Howard WJ, Wang W, Best L, Lee ET: Incidence and risk factors for stroke in American Indians: the strong heart study. Circulation 2008;118: 1577-1584.
9 Kistorp C, Raymond I, Pedersen F, Gustafsson F, Faber J, Hildebrandt P: N-terminal pro-brain natriuretic peptide, C-reactive protein, and urinary albumin levels as predictors of mortality and cardiovascular events in older adults. JAMA 2005;293:16091616.

10 Wachtell K, Ibsen H, Olsen MH, BorchJohnsen K, Lindholm LH, Mogensen CE, Dahlof B, Devereux RB, Beevers G, de Faire U, Fyhrquist F, Julius S, Kjeldsen SE, Kristianson K, Lederballe-Pedersen $\mathrm{O}$, Nieminen MS, Okin PM, Omvik P, Oparil S, Wedel H, Snapinn SM, Aurup P: Albuminuria and cardiovascular risk in hypertensive patients with left ventricular hypertrophy: the life study. Ann Intern Med 2003;139:901-906.

11 Hill AB: The environment and disease: association or causation? Proc R Soc Med 1965; 58:295-300.

12 Thomas GN, Lin JW, Lam WW, Tomlinson B, Yeung V, Chan JC, Wong KS: Middle cerebral artery stenosis in type II diabetic chinese patients is associated with conventional risk factors but not with polymorphisms of the renin-angiotensin system genes. Cerebrovasc Dis 2003; 16:217-223.
13 Thomas GN, Chen XY, Lin JW, Tomlinson B, Lam WW, Liu R, Yeung VT, Chan JC, Wong KS: Middle cerebral artery stenosis increased the risk of vascular disease mortality among type 2 diabetic patients. Cerebrovasc Dis 2008;25:261-267.

14 Schiffrin EL, Lipman ML, Mann JF: Chronic kidney disease: effects on the cardiovascular system. Circulation 2007;116:85-97.

15 Roquer J, Segura T, Serena J, Castillo J: Endothelial dysfunction, vascular disease and stroke: the ARTICO study. Cerebrovasc Dis 2009;27(suppl 1):25-37.

16 Grabska K, Niewada M, Sarzynska-Dlugosz I, Kaminski B, Czlonkowska A: Pulse pressure: independent predictor of poor early outcome and mortality following ischemic stroke. Cerebrovasc Dis 2009;27:187-192.

17 Yoo EG, Choi IK, Kim DH: Prevalence of microalbuminuria in young patients with type 1 and type 2 diabetes mellitus. J Pediatr Endocrinol Metab 2004;17:1423-1427.

18 Liu JE, Robbins DC, Palmieri V, Bella JN, Roman MJ, Fabsitz R, Howard BV, Welty TK, Lee ET, Devereux RB: Association of albuminuria with systolic and diastolic left ventricular dysfunction in type 2 diabetes: the Strong Heart Study. J Am Coll Cardiol 2003; 41:2022-2028. 